\title{
Transoesophageal echocardiographic assessment of fixed subaortic obstruction in children
}

\author{
J P Gnanapragasam, A B Houston, W B Doig, M P G Jamieson, J C S Pollock
}

\begin{abstract}
Objective-To evaluate the clinical usefulness of transoesophageal echocardiography in the assessment of children with fixed left ventricular outflow tract stenosis.
\end{abstract}

Patients and methods-Eight consecutive children, aged over 5 years, with fixed subaortic stenosis and one child with fixed subpulmonary left ventricular outflow tract stenosis were prospectively assessed by precordial and transoesophageal echocardiography.

Results-Transoesophageal images of the left ventricular outflow tract were much clearer than precordial images in all patients except one with a prosthetic mitral valve. Improved visualisation provided further information on the nature of the lesion (additional chordal attachment of the mitral valve in one, accessory atrioventricular valve tissue with aneurysm formation in one), on the extent of the lesion (circumferential in three), and on the very close relation of a ridge to the aortic valve leaflets in one. Transoesophageal Doppler did not provide any additional information on aortic regurgitation and was unreliable for gradient estimation across the left ventricular outflow tract.

Conclusions-Transoesophageal imaging provides an excellent means of visualising lesions in the left ventricular outflow tract and can be useful in a few children and adolescents in whom precordial echocardiography does not provide adequate information. The technique can also be used intraoperatively to define the full extent of the obstructive lesion and to assess residual lesions after surgery.

Departments of Cardiology and Cardiac Surgery, Royal Hospital for Sick Children, Sick Childrow

Glasgow A B Houston W B Doig W P G Jamieson J C S Pollock

Correspondence to Dr J P Gnanapragasam, Departmnent of Cardiology, Royal Hospital for Sick Children, Glasgow G3 8SJ

Accepted for publication 10 May 1991
Fixed subaortic stenosis is a relatively uncommon cause of obstruction to the outflow of the left ventricle but is important because it requires, earlier intervention than in aortic valve stenosis. The nature of the lesion, its circumferential extent, and its relation to the aortic valve leaflets can vary. Precordial echocardiography, currently the investigation of choice in these patients, will identify a subaortic lesion in most children but may fail to show it in a few. ${ }^{1}$ Transoesophageal echocardiography permits clear visualisation of lesions of the left ventricular outflow tract and has been reported to be useful in adults with inconclusive precordial findings. ${ }^{23}$ The technique usually requires general anaesthesia in children and any benefits have to be balanced against this. We report our experience when we used this technique to assess left ventricular outflow tract obstruction in children.

\section{Patients and methods}

Eight consecutive children, aged over 5 years, with fixed subaortic obstruction were assessed. During the study period a child presented with fixed subpulmonary obstruction in the presence of transposition of the great arteries and was also included in the assessment. We excluded children aged $<5$ because a standard (adult) sized transducer was used for the transoesophageal study. Table 1 shows the ages and details of previous surgery. All patients were symptom free but had physical signs of left ventricular outflow obstruction, and two (patients 3 and 6) also had the murmur of aortic regurgitation. All were assessed initially by precordial imaging and Doppler echocardiography and five were referred for surgery without further investigations. Three patients underwent cardiac catheterisation. A patient with recurrent subaortic stenosis and poor precordial views underwent cardiac catheterisation before surgery (patient 1). Patient 2 who had a bicuspid aortic valve and a prosthetic mitral valve was catheterised to better define the site and severity of obstruction and underwent a transoesophageal study at the same time. Patient 9 had a baffle leak and pulmonary venous obstruction after Mustard repair and

Table 1 Age at transoesophageal echocardiography (TOE) and details of previous surgery

\begin{tabular}{|c|c|c|}
\hline Patient & $\begin{array}{l}\text { Age at } \\
\text { TOE study }\end{array}$ & Previous surgery (age) \\
\hline 1 & 13 yr 4 month & $\begin{array}{l}\text { Repair of atrioventricular septal } \\
\text { defect and resection of subaortic } \\
\text { ridge ( } 3 \text { yr } 10 \text { month) }\end{array}$ \\
\hline 2 & 5 yr 2 month & $\begin{array}{l}\text { Repair of coarctation ( } 6 \text { days) } \\
\text { Mitral valve replacement ( } 2 \text { yr } 3 \\
\text { month) }\end{array}$ \\
\hline 3 & 12 yr 2 month & $\begin{array}{l}\text { Repair of coarctation ( } 8 \mathrm{yr} 9 \\
\text { month) } \\
\text { Resection of subaortic ridge ( } 9 \text { yr } 7 \\
\text { month) }\end{array}$ \\
\hline $\begin{array}{l}4 \\
5\end{array}$ & $\begin{array}{l}6 \mathrm{yr} \\
14 \mathrm{yr} 10 \text { month }\end{array}$ & $\begin{array}{l}\text { None } \\
\text { None }\end{array}$ \\
\hline $\begin{array}{l}3 \\
6\end{array}$ & 9 yr 7 month & $\begin{array}{l}\text { Ligation of ductus arteriosus ( } 4 \mathrm{yr} \\
10 \text { month) }\end{array}$ \\
\hline $\begin{array}{l}7 \\
8 \\
9\end{array}$ & $\begin{array}{l}7 \text { yr } 5 \text { month } \\
5 \text { yr } 5 \text { month } \\
7 \text { yr } 3 \text { month }\end{array}$ & $\begin{array}{l}\text { None } \\
\text { None } \\
\text { Mustard procedure ( } 3 \text { yr } 10 \\
\text { month) }\end{array}$ \\
\hline
\end{tabular}


Table 2 Precordial and transoesophageal echocardiographic findings in nine patients

\begin{tabular}{|c|c|c|}
\hline Patient & Precordial findings & Transoesophageal findings \\
\hline \multirow[t]{2}{*}{1} & Poorly defined projection on posterior aspect of LVOT & $\begin{array}{l}\text { Prominent accessory atrioventricular valve tissue and a } \\
\text { small ridge over the septum }\end{array}$ \\
\hline & $\begin{array}{l}\text { LVOT gradient } 75 \mathrm{~mm} \mathrm{Hg} \\
\text { AR }\end{array}$ & $\begin{array}{l}\text { Gradient not measurable } \\
\text { AR }\end{array}$ \\
\hline \multirow[t]{2}{*}{2} & $\begin{array}{l}\text { Bicuspid aortic valve } \\
\text { Prosthetic mitral valve projecting into LVOT } \\
\text { Small projection over septum }\end{array}$ & Shadow of prosthetic valve masking LVOT \\
\hline & $\begin{array}{l}\text { LVOT gradient } 100 \mathrm{~mm} \mathrm{Hg} \\
\text { AR }\end{array}$ & $\begin{array}{l}\text { Gradient not measurable } \\
\text { AR }\end{array}$ \\
\hline 3 & $\begin{array}{l}\text { Small subaortic ridge just below aortic valve } \\
\text { LVOT gradient } 85 \mathrm{~mm} \mathrm{Hg} \\
\text { AR }\end{array}$ & $\begin{array}{l}\text { Circumferential ridge at site of insertion of valve leaflets } \\
\text { Gradient not measurable } \\
\text { AR }\end{array}$ \\
\hline 4 & Subaortic shelf clearly seen on septal aspect of LVOT & $\begin{array}{l}\text { Smaller shelf on mitral aspect forming a circumferential } \\
\text { ridge }\end{array}$ \\
\hline 5 & $\begin{array}{l}\text { LVOT gradient } 65 \mathrm{~mm} \mathrm{Hg} \\
\text { Ridge over septum } \\
\text { LVOT gradient } 70 \mathrm{~mm} \mathrm{Hg} \\
\text { AR }\end{array}$ & $\begin{array}{l}\text { Gradient not measurable } \\
\text { No additional findings } \\
\text { Gradient not measurable } \\
\text { AR }\end{array}$ \\
\hline 6 & $\begin{array}{l}\text { Circumferential ridge more prominent over septum } \\
\text { LVOT gradient } 70 \mathrm{~mm} \mathrm{Hg} \\
\text { AR }\end{array}$ & $\begin{array}{l}\text { No additional findings } \\
\text { Gradient not measurable } \\
\text { AR }\end{array}$ \\
\hline 7 & $\begin{array}{l}\text { Circumferential ridge more prominent over septum } \\
\text { LVOT gradient } 100 \mathrm{~mm} \mathrm{Hg} \\
\text { AR }\end{array}$ & $\begin{array}{l}\text { No additional findings } \\
\text { Gradient not measurable } \\
\text { AR }\end{array}$ \\
\hline 8 & $\begin{array}{l}\text { Circumferential subaortic ridge } \\
\text { LVOT gradient } 80 \mathrm{~mm} \mathrm{Hg} \\
\text { AR }\end{array}$ & $\begin{array}{l}\text { No additional findings } \\
\text { Gradient not measurable } \\
\text { AR }\end{array}$ \\
\hline 9 & $\begin{array}{l}\text { Small ridge over mitral and septal aspects of LVOT } \\
\text { LVOT gradient } 70 \mathrm{~mm} \mathrm{Hg}\end{array}$ & $\begin{array}{l}\text { Additional chordal attachment of mitral valve to septum } \\
\text { Gradient not measurable }\end{array}$ \\
\hline
\end{tabular}

LVOT, left ventricular outflow tract; AR, aortic regurgitation.

underwent cardiac catheterisation to assess the state of the baffle before surgery. Transoesophageal echocardiography was performed as a primary diagnostic procedure in a patient with recurrent subaortic stenosis in whom the precordial images were an inadequate basis for a decision on re-operation (patient 3 ). Seven patients have so far undergone surgery and all had intraoperative transoesophageal studies.

The echocardiographic studies were performed with a Vingmed 700 ultrasound machine. We used a $5.0 \mathrm{MHz}$ frequency standard (adult) sized transoesophageal transducer with facilities for transverse plane imaging, and pulsed, continuous wave, and colour Doppler. The left ventricular outflow tract was viewed by angulation of the oesophageal transducer to obtain a long axis view of the left ventricle. Surgical confirmation of the lesion was possible in the seven patients who had surgery.

\section{Results}

The studies were assessed to determine

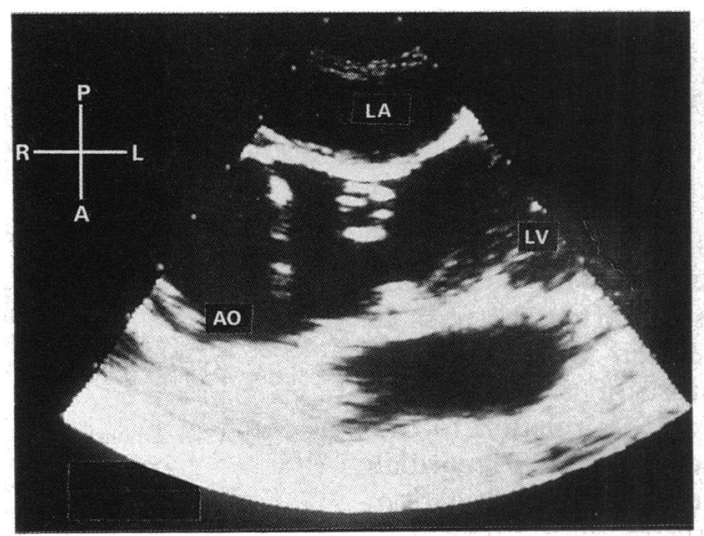

Figure 1 Transoesophageal echocardiogram clearly showing prominent accessory left atrioventricular valve tissue which looked like a cyst in systole and collapsed in diastole and also showing a slight ridge over the septum (patient 1). LA, left atrium; $L V$, left ventricle; $A O$, aorta. whether the transoesophageal technique gave more information than the precordial technique.

\section{COMPARISON OF TRANSTHORACIC AND}

TRANSOESOPHAGEAL ECHOCARDIOGRAPHY FINDINGS

Table 2 shows the findings obtained by the two methods.

\section{Imaging}

In patient 1 who was obese and had very poor precordial images transoesophageal echocardiography clearly showed accessory atrioventricular valve tissue which formed a blood filled aneurysm in the left ventricular outflow tract during systole and also showed a slight ridge over the septum (fig 1 ). The transoesophageal demonstration of this lesion was also much better than the angiographic images obtained in this patient. In the patient with the fixed subpulmonary obstruction transoesophageal imaging showed that an unsuspected additional chordal attachment of the mitral

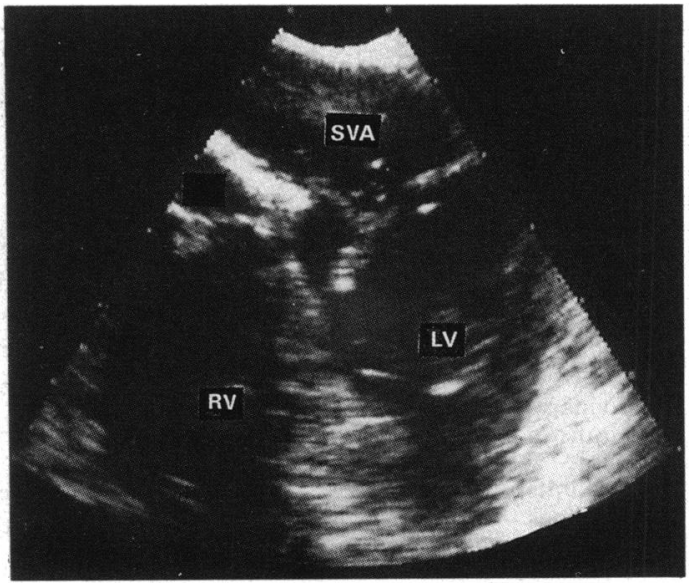

Figure 2 Transoesophageal echocardiogram (long axis view) of the left ventricle in patient 9 showing additional chordal attachment of the mitral valve to the left ventricular outflow tract. SVA, systemic venous atrium; $L V$, left ventricle; $R V$, right ventricle. 


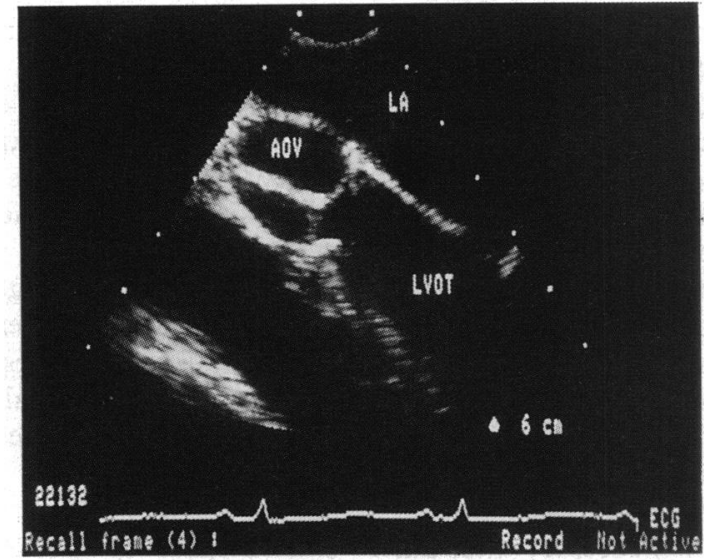

Figure 3 Transoesophageal echocardiogram showing the very close relation of the recurrent subaortic ring to the insertion of the aortic valve leaflets (patient 3 ). LA, left atrium; $A O V$, aortic valve; $L V O T$, left ventricular outflow tract.

valve obstructed flow through the left ventricular outflow tract (fig 2). The very close attachment of the recurrent subaortic ridge to the undersurface of the aortic valve leaflets was much better shown by transoesophageal imaging in patient 3 (fig 3). Transoesophageal echocardiography showed the circumferential nature of the obstruction in patient 4 -that is, the smaller ridge on the mitral side as well as the prominent ridge on the septum seen by precordial imaging. No additional diagnostic information was provided by transoesophageal echocardiography in four other patients though the obstructive lesions were much more clearly shown (fig 4). In the patient with a mitral valve prosthesis (patient 2) transoesophageal viewing of the left ventricular outflow was limited owing to shadowing by the prosthetic valve and no additional information was obtained.

\section{Doppler}

A precordial view showed the maximum velocity across the left ventricular outflow tract

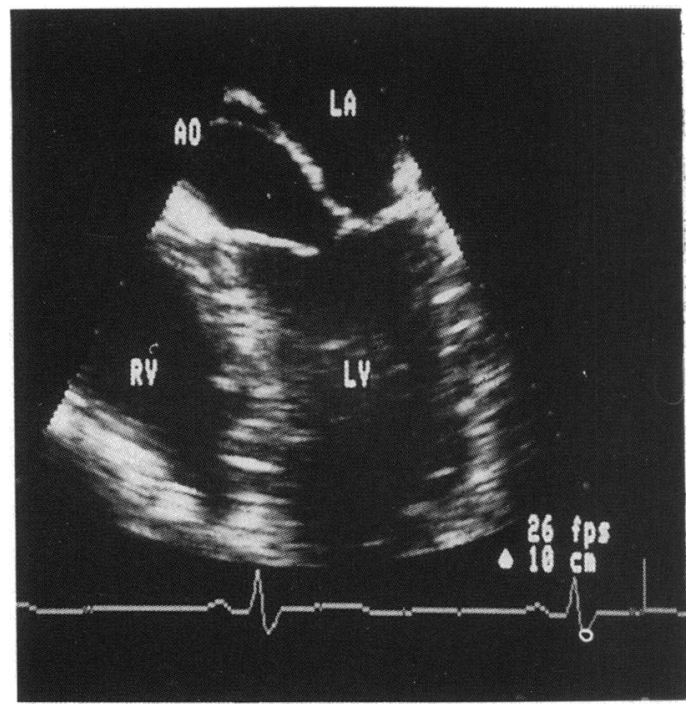

Figure 4 Transoesophageal echocardiogram (long axis view) of the left ventricle in a 14 year old showing a very prominent subaortic shelf projecting into the left ventricular outflow tract in systole (patient 6 ). LA, left atrium; $L V$, left ventricle; $A O$, aorta; $R V$, right ventricle. in all patients by continuous wave Doppler when the position and direction of the transducer was adjusted to give a complete spectral signal showing the highest velocity. This could not be reliably determined by the oesophageal route because the Doppler beam could not be aligned with flow through the left ventricular outflow tract in any patient. Aortic regurgitation was detected by both transoesophageal and precordial Doppler in seven patients.

\section{Postoperative transoesophageal} echocardiography studies

Intraoperative transoesophageal imaging after surgery and discontinuation of bypass showed complete resection of the ridge in all cases except patients 1 and 9. A small projection remained on the mitral aspect of the left ventricular outflow tract in patient 1 but because the fibromuscular tissue had been extensively resected and the left ventricular outflow tract appeared widely patent the result was considered acceptable. A small ridge remained on the septum in patient 9 , in whom the small accessory papillary muscle was resected through a pulmonary arteriotomy, but there was no evidence of mitral regurgitation. During resection of the subaortic ridge in patient 8 the anterior leaflet of the mitral valve was breached and was oversewn with a single suture. Postoperative colour Doppler echocardiography showed a small colour jet of mitral regurgitation from the point of coaption of the mitral leaflets (as had been noted preoperatively) and no leak through the sutured region of the valve. Postoperative colour Doppler examination also showed persistence of aortic regurgitation in seven patients as noted preoperatively.

\section{Discussion}

The presence of a subaortic ridge can be confirmed by precordial echocardiography in most children. ${ }^{1}$ In a few patients, however, image definition may not be good enough to allow a decision on surgery. Cardiac catheterisation can be undertaken in such cases but angiographic demonstration of the lesion can also be poor if the shelf is thin. ${ }^{5}$

In our series transoesophageal echocardiography provided excellent images of the left ventricular outflow tract in all patients except one with a prosthetic mitral valve. The clarity of the images obtained led to an accurate definition of the nature of the obstructive lesion, its circumferential extent across the left ventricular outflow tract, and its relation to the aortic valve leaflets. This technique is not reliable for gradient estimation because the left ventricular outflow tract is obliquely orientated in relation to the oesophagus and it is difficult to align a Doppler beam from the oesophagus parallel with the jet caused by the subaortic obstruction, which is often eccentric. The gradient can be easily estimated by precordial Doppler, however. The presence of physical signs of left ventricular outflow obstruction together with precordial echocardiographic confirmation of the lesion is sufficient for most 
children to proceed to surgery because discrete subaortic stenosis is a progressive lesion that leads to damage to the aortic valve and left ventricular myocardium. ${ }^{5}$ A transoesophageal study under general anaesthesia is therefore not required to obtain further information before surgical referral in most children. Intraoperative use of this technique can nevertheless be valuable in defining the full extent of the lesion before surgery and detecting residual lesions and assessing function of the mitral valve after surgery. Intraoperative epicardial echocardiography has recently been reported to be valuable in the same situation. ${ }^{6}$

Long term follow up is necessary after surgery because the obstruction recurs in up to $27 \%$ of patients. ${ }^{7}$ Precordial images of recurrent lesions in adolescents may not be as satisfactory as those obtained in younger children and transoesophageal echocardiography can be useful in this group of patients. In one of our adolescent patients (patient 1) with poor precordial images transoesophageal echocardiography showed the obstructive lesion better than angiography. In patient 3 transoesophageal echocardiography was helpful in defining the attachment of the small recurrent circumferential ridge to the undersurface of the insertion of the aortic valve leaflets (fig 3). Because further resection of the subaortic ridge could have damaged the aortic valve leaflets and led to valve replacement and because the patient was symptom free surgery was deferred. We believe that transoesophageal echocardiography rather than cardiac catheterisation is the preferred method of demonstrating a subaortic lesion if standard echo- cardiography does not provide sufficient information.

Transoesophageal echocardiography permits improved assessment of the nature and extent of lesions of the left ventricular outflow tract and can be of use in the few children in whom precordial echocardiography is inadequate for a management decision. In most children with left ventricular outflow tract obstructions transoesophageal echocardiography is not essential for preoperative diagnosis and its main role is in the intraoperative assessment.

JPG is supported by a grant from the Equipment Evaluation Committee of the Scottish Home and Health Department. We thank Mr E Murtagh and Mr S Lilley for their technical assistance.

1 Motro M, Schneeweiss A, Shem-Tov A, et al. Two dimensional echocardiography in discrete subaortic stenosis. $A m$ J Cardiol 1984;53:896-8.

2 Schwinger ME, Kronzon I. Improved evaluation of left ventricular outflow tract obstruction by transesophageal echocardiography. J Am Soc Echocardiogr 1989;2:191-4.

3 Mugge A, Daniel WG, Wolpers HG, Klopper JW, Lichtlen PR. Improved visualisation of discrete subvalvular aortic stenosis by transoesophageal color-coded Doppler echocardiography. Am Heart J 1989;117:474-6.

4 Seward JB, Khandheria BK, Oh JK, et al. Transoesophageal echocardiography: technique, anatomic correlations, implementation, and applications. Mayo Clin Proc 1988; 63:649-80.

5 Somerville J. Aortic stenosis and incompetence. In: Anderson RH, Macartney FJ, Shinebourne EA, Tynan M, eds. Paediatric cardiology. Edinburgh: Churchill Livingstone, 1987:987-92.

6 Sreeram N, Sutherland GR, Bogers JJC, et al. Subaortic obstruction: intraoperative echocardiography as an adjunct to operation. Ann Thorac Surg 1990;50:579-85.

7 Stewart JR, Merrill WH, Hammon JW, Graham TP, Bender HW. Reappraisal of localized resection for subvalvar aortic stenosis. Ann Thorac Surg 1990;50: 197-203. 